University of Nebraska - Lincoln

DigitalCommons@University of Nebraska - Lincoln

Faculty Publications from the Harold W. Manter Laboratory of Parasitology

2-1991

\title{
Heliconema brooksi n. sp. (Nematoda: Physalopteridae) from the Ophichthid Eel Ophichthus gomesi in the Gulf of Mexico
}

John L. Crites

Ohio State University

Robin M. Overstreet

Gulf Coast Research Laboratory, robin.overstreet@usm.edu

Follow this and additional works at: https://digitalcommons.unl.edu/parasitologyfacpubs

Part of the Parasitology Commons

Crites, John L. and Overstreet, Robin M., "Heliconema brooksi n. sp. (Nematoda: Physalopteridae) from the Ophichthid Eel Ophichthus gomesi in the Gulf of Mexico" (1991). Faculty Publications from the Harold W. Manter Laboratory of Parasitology. 300.

https://digitalcommons.unl.edu/parasitologyfacpubs/300

This Article is brought to you for free and open access by the Parasitology, Harold W. Manter Laboratory of at DigitalCommons@University of Nebraska - Lincoln. It has been accepted for inclusion in Faculty Publications from the Harold W. Manter Laboratory of Parasitology by an authorized administrator of DigitalCommons@University of Nebraska - Lincoln. 


\title{
HELICONEMA BROOKSI N. SP. (NEMATODA: PHYSALOPTERIDAE) FROM THE OPHICHTHID EEL OPHICHTHUS GOMESI IN THE GULF OF MEXICO
}

\author{
John L. Crites* and Robin M. Overstreet \\ Gulf Coast Research Laboratory, Ocean Springs, Mississippi 39564
}

\begin{abstract}
Heliconema brooksi n. sp. is described from the shrimp eel, Ophichthus gomesi, in Mississippi Sound. This species is distinguished from other members of the genus by possessing in the male 40 or more tessellated longitudinal ridges, a spicule ratio averaging 1:10.6, 4 precloacal papillae, and 6 postcloacal papillae. Females have a protruding vulvular flap. Both sexes have a prominent sclerotized cardium. Heliconema brooksi is morphologically most closely related to Heliconema heliconema. A juvenile worm from the white shrimp, Penaeus setiferus, in the same locality may be the infective stage.
\end{abstract}

Few physalopterids infect fish, and most that do infect elasmobranch fishes. Members of some genera including the fish-infecting Heliconema also infect reptiles. This report describes a new species of Heliconema commonly occurring in the stomach of the shrimp eel, Ophichthus gomesi, from Mississippi Sound near Ocean Springs, Mississippi.

\section{MATERIALS AND METHODS}

Some specimens were killed in glacial acetic acid and preserved in $10 \%$ formalin or $70 \%$ ethyl alcohol plus $5 \%$ glycerine; others were heat killed and preserved in $70 \%$ ethanol alcohol. Nematodes for study using scanning electron microscopy (SEM) were fixed in Karnovsky's solution, buffered in $0.1 \mathrm{M}$ cacodylate $(\mathrm{NaCaC})$, postfixed in $\mathrm{OsO}_{4}$, rinsed in $0.1 \mathrm{M} \mathrm{NaCaC}$, dehydrated, critical-point dried, and gold sputter coated. These worms were examined with a JEOL JSMT330 scanning electron microscope. All nematodes used for measurements were sexually mature, killed with glacial acetic acid, preserved in $70 \%$ alcohol plus $5 \%$ glycerine, and mounted in glycerine. Line drawings were prepared with the aid of a drawing tube. All measurements are given in micrometers unless otherwise indicated.

\section{DESCRIPTION \\ Heliconema brooksi n. sp. \\ (Figs. 1-32)}

General: Body chalky white when alive but many appearing brownish-orange with low magnification because of extraenteric pigmented cells; anterior cuticle reflected forming cephalic collarette. Mouth dorsoventrally elongate, with 2 lateral pseudolips; pseudolips each bearing 1 lateral amphid and 2 submedian pa-

Received 7 May 1990; revised 26 July 1990; accepted 26 July 1990.

* Present address: Museum of Zoology, The Ohio State University, 1735 Neil Avenue, Columbus, Ohio 43210. Please direct all reprint requests to Robin Overstreet. pillae; inner lip surface of each pseudolip with large median conical tooth and ridged subdorsal and subventral teeth. Esophagus divided into 3 regions; anterior 2 regions relatively short, approximately equal in length, muscular; posterior portion relatively long, glandular, joining intestine through prominent muscular and sclerotized valve. Nerve ring in posterior half of muscular esophagus; deirids (cervical papillae) lateral at level of nerve ring. Excretory pore near junction of muscular-glandular portions of esophagus. Tail typically blunt.

Male (based on 22 mature specimens; range, mean): Body $10.5-20.9 \mathrm{~mm}$ (14.3 mm) long by 198-290 (216) wide at nerve ring, with width increasing posteriorly to 285-396 (309) at greatest width, 44 times longer than wide. Posterior portion coiled at least 3 times in living specimens. Collarette 161-187 (177) across, 197259 (221) in length. Esophagus 1.6-3.3 mm (2.1 mm) in total length, $12.6-16.6 \%(14.4 \%)$ of body length; complete muscular portion 274-433 (309) long, 12.5$17.4 \%(14.6 \%)$ of total esophageal length; glandular portion 1,601-2,966 (1,818) long by 111-197 (123) wide. Esophageal-intestinal valve 68-105 (86) long. Nerve ring 198-290 (216) from anterior end. Deirids 197-268 (213) from cephalic end. Excretory pore 290 370 (325) from anterior end. Testis sinuous, reflexed, 3.67-7.14 mm $(5.18 \mathrm{~mm})$ from cephalic end. Spicules dissimilar in shape, unequal in length; left spicule relatively long, $2.09-3.50 \mathrm{~mm}(2.96 \mathrm{~mm})$ in length, narrow, tapering to fine point distally; right spicule relatively short, 204-328 (268) long, arcuate, thicker than left spicule, with proximal end capitate, with distal end recurved, hooked; spicule ratio 1:9.1-12.5 (1:10.6). Gubernaculum absent. Caudal alae approximately 4 times length of tail, slightly expanded, not united anteriorly, containing 10 symmetrical pairs of caudal papillae; each papilla coursing through alae, terminating distally as distinct circular sensilla on ventral external alar surface; precloacal papillae 4 pairs, of equal lengths, arranged in 2 groups of 2 pairs each; postcloacal papillae 6 pairs, in 4 groups of $1,2,1$, and 2 small pairs; peduncles irregular in shape, often with lateral branches or bulbous expansions, sometimes swollen distally; branches asymmetrical, unilateral or bilateral, swollen or similar in diameter to trunk of peduncle. Phasmids not observed. Cloacal vent appearing as transverse opening in prominent, midventral knoblike projection 

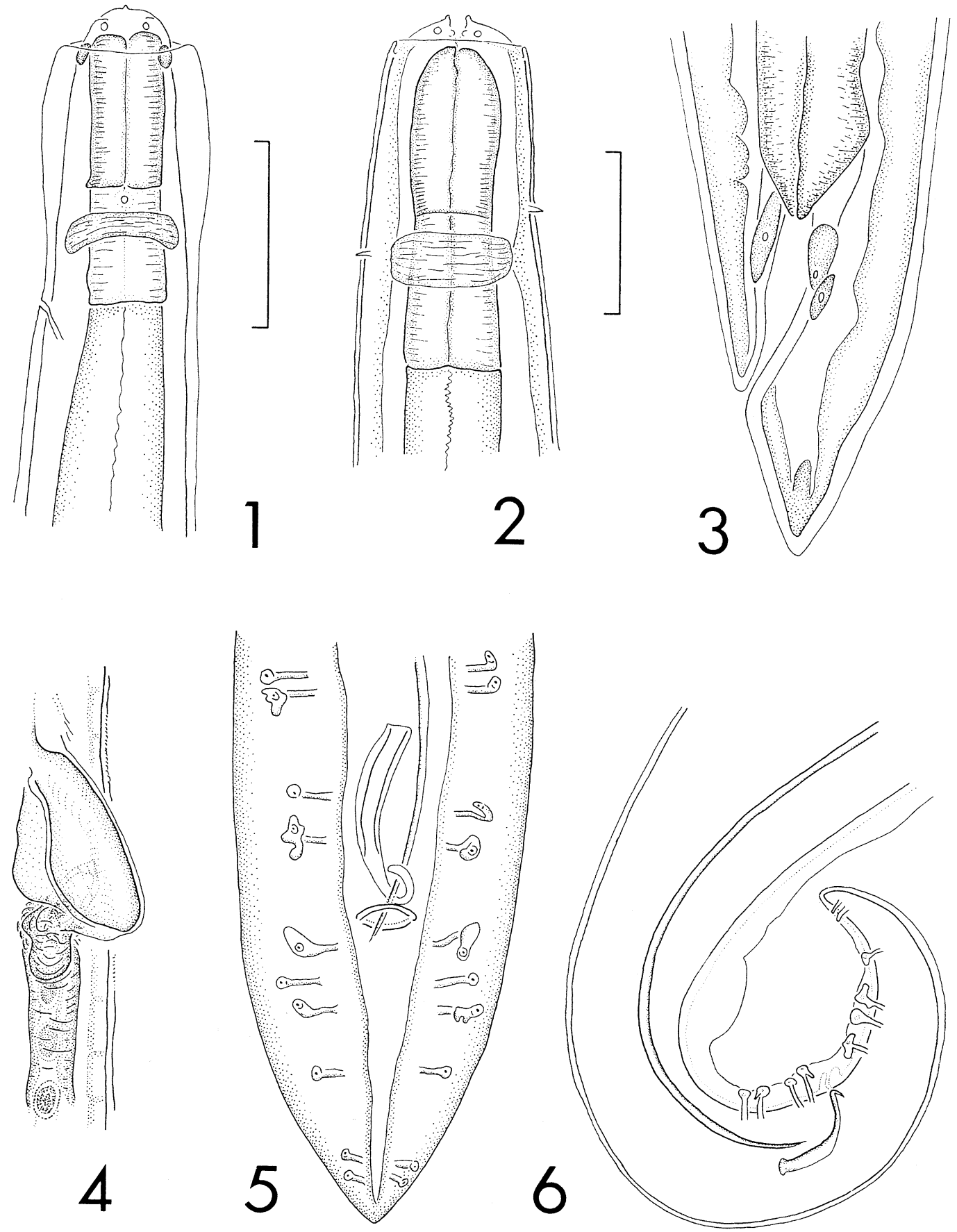

FIGURES 1-6. Heliconema brooksi n. sp. from shrimp eel; scale bar $=200 \mu \mathrm{m}$ on Figure 1 also serves Figures 3-6. 1. Anterior end, lateral view, normal appearing collarette, male. 2. Anterior end, ventral view, collapsed collarette, female; bar $=500 \mu \mathrm{m}$. 3. Young female tail, lateral view. 4. Vagina vera associated with vulvular flap. 5. Disposition of caudal papillae in relationship to alae, cloacal vent, and spicules, ventral view. 6. Posterior end of male showing spicules, papillae, and genital bulb, lateral view. 

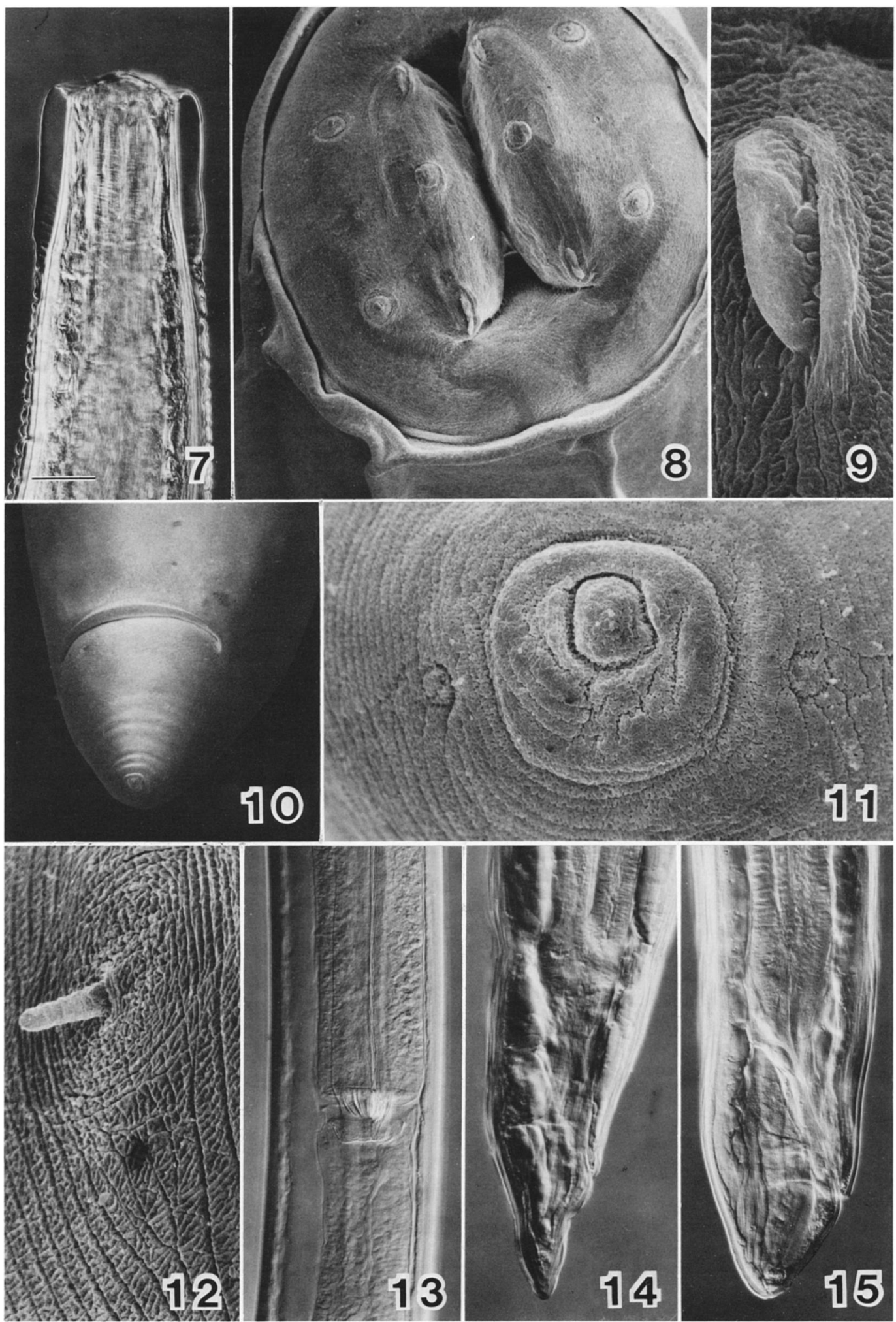
between the alae. Ventral cuticle forming 40 or more rows of tessellated longitudinal ridges; ridges extending anteriorly more than $20 \%$ of body length from knoblike projection. Posterior end coiled ventrally; tail flexed, 372-531 (398) long.

Female (based on 18 mature specimens): Body 14.1$30.0 \mathrm{~mm}(19.4 \mathrm{~mm})$ long by $210-253$ (216) wide at the nerve ring, increasing in width posteriorly to $352-$ $494(418)$ at the greatest width, 47 times longer than wide. Collarette 185-256 (224) across, 198-414 (252) in length. Esophagus $2.1-3.4 \mathrm{~mm}(2.6 \mathrm{~mm})$ in total length, $11.4-15.4 \%$ (13.6\%) of body length; total muscular portion $277-457$ (379) long, 11.9-17.7\% (13.8\%) of entire esophagus; glandular portion 1,798-2,948 $(2,237)$ long by 123-234 (149) wide. Esophageal-intestinal valve 74-129 (88) long. Nerve ring 203-414 (263) from cephalic end. Deirids 198-400 (258) from anterior end. Excretory pore 272-414 (328) from anterior end. Vulva with prominent protruding flap, situated $6.3-12.2 \mathrm{~mm}(8.7 \mathrm{~mm})$ or $42-48 \%(44 \%)$ of body length from anterior end. Vagina muscular, 1,400-1,701 $(1,586)$ long; uterus didelphic, amphidelphic; uterine sacs each associated with single seminal receptacle and single ovary. Oviduct highly muscular, with valve occurring at entrance to pyriform seminal receptacle; seminal receptacle with sphincter at entrance to uterus; anterior reproductive organs more extended and less coiled than posterior ones. Larvated eggs $37-43$ long by 29-31 wide. Rectum 173-371 (259) long, surrounded by 3 rectal glands anteriorly. Tail tapered, more rounded and blunt in larger specimens 167-241 (195) long. Phasmids 12 from tip of tail.

\section{Taxonomic summary}

Type host: Ophichthus gomesi (Castelnau) (Pisces: Ophichthidae), shrimp eel.

Site: Stomach.

Prevalence: Common in relatively large specimens of the shrimp eel, especially from May through autumn.

Type locality: Mississippi Sound, Gulf of Mexico. Specimens deposited: Holotype (male) National Parasite Collection, USNM Helm. Coll. no. 81171; allotype (female) USNM Helm. Coll. no. 81172; paratypes ( 2 males and 2 females) USNM Helm. Coll. no. 81173; ( 2 males and 2 females) H. W. Manter Laboratory, University of Nebraska State Museum, HWML No. 33105; ( 2 males and 2 females) Gulf Coast Research Laboratory Museum, GCRL no. 1138.

Etymology: The species is named in honor of Daniel
Brooks for his contributions to helminthology as well as his interest in the species.

Probable intermediate host: Penaeus setiferus (Linnaeus, 1767) (Crustacea: Penaeidae), white shrimp. Under the rostral exoskeleton of 1 specimen of the shrimp occurred a juvenile nematode, probably a third stage molting its second stage cuticle, possibly conspecific with $H$. brooksi (Figs. 33-35). It had an esophagus $36.4 \%$ of the $1.52-\mathrm{mm}$-long body, divided into a $166-$ long anterior muscular portion and a 586-long glandular portion. The esophagus had a prominent sclerotized and muscular valve joining the intestine as in preadult and adult $H$. brooksi. The anterior end did not have a distinct collarette, but there were 2 lips, each with 2 prominent cephalic papillae. The cuticle had definite annuli and at the tip of the tail occurred 4 distinct mucrones. All characteristics of this juvenile fit those reported for physalopteroids from fishes.

\section{Remarks}

Heliconema brooksi differs from other species in the genus in that the male has 40 or more irregularly interrupted, tessellated, longitudinal cuticular ridges in the posterior quarter of the body. Heliconema heliconema and Heliconema brevispiculum have 20 longitudinal ridges, and Heliconema psammobatidus has 14; the spicule ratios (right/left) are $1: 20$ or $12.7,1: 2.4$, and 1:4.2, respectively, as opposed to $1: 10.6$ in $H$. brooksi. Two ratios are reported for $H$. heliconema from different sets of specimens. Guimarães et al. (1976) reported $H$. heliconema from Ophichthus ophis collected off Salvador, Bahia, Brazil. We obtained these specimens on loan from the helminthological collection of the Institute of Oswaldo Cruz (no. 31.239a-d, no. 14.047). They fit all the characteristics described for $H$. heliconema by Travassos (1919) well, including the spicule lengths that have an average ratio of $1: 12.7$. This ratio differs from that of 1:20 given by Fusco and Palmieri (1980). Their reported ratio of 1:20 apparently was based on remeasurements made by Ogden (1969) from specimens collected from Echidna peli and Echidna lecomtei from Dakar, Senegal; they were identified as $H$. heliconema by Campana-Rouget (1956), but we suspect they may represent a new, closely related species. Three additional records from the eel Muraenesox cinereus in Pakistan and India also report the species with a spicule ratio of at least 1:20 (Soota, 1983). Heliconema heliconema, $\boldsymbol{H}$. brevispiculum, and $H$. psammobatidus have females with protruding vulvular structures, and $H$. brooksi has a prominent vulvular flap.

FIGURES 7-15. Heliconema brooksi $\mathrm{n}$. sp. from shrimp eel; scale bar on Figure 7 serves all figures. 7. Anterior end of worm killed in glacial acetic acid and preserved in $70 \%$ alcohol plus $5 \%$ glycerine, lateral view. Note collarette, 2 parts of muscular anterior esophagus, and position of nerve ring; bar $=83 \mu \mathrm{m}$. 8. SEM of anterior end, en face. Note 2 pseudolips with inner teeth, lateral small amphids, submedian papillae, and collapsed collarette; bar $=14 \mu \mathrm{m}$. 9. SEM of ridged subventral tooth; bar $=2.0 \mu \mathrm{m}$. 10. SEM of posterior end of large female showing transverse anus and blunt tail; bar $=49 \mu \mathrm{m}$. 11. SEM of tip of same tail shown in Figure 10. Note the lateral phasmids; bar $=4.8 \mu \mathrm{m}$. 12. SEM of deirid extending through cuticular surface. Note circular cuticular area interrupting normal pattern of annuli; bar $=2.8 \mu \mathrm{m}$. 13. Esophageal-intestinal valve at posterior end of glandular esophagus; bar $=132 \mu \mathrm{m}$. 14. Sharp tail of small female, lateral view; bar $=87 \mu \mathrm{m}$. 15. Blunt tail of larger female, lateral view; bar $=84 \mu \mathrm{m}$. 

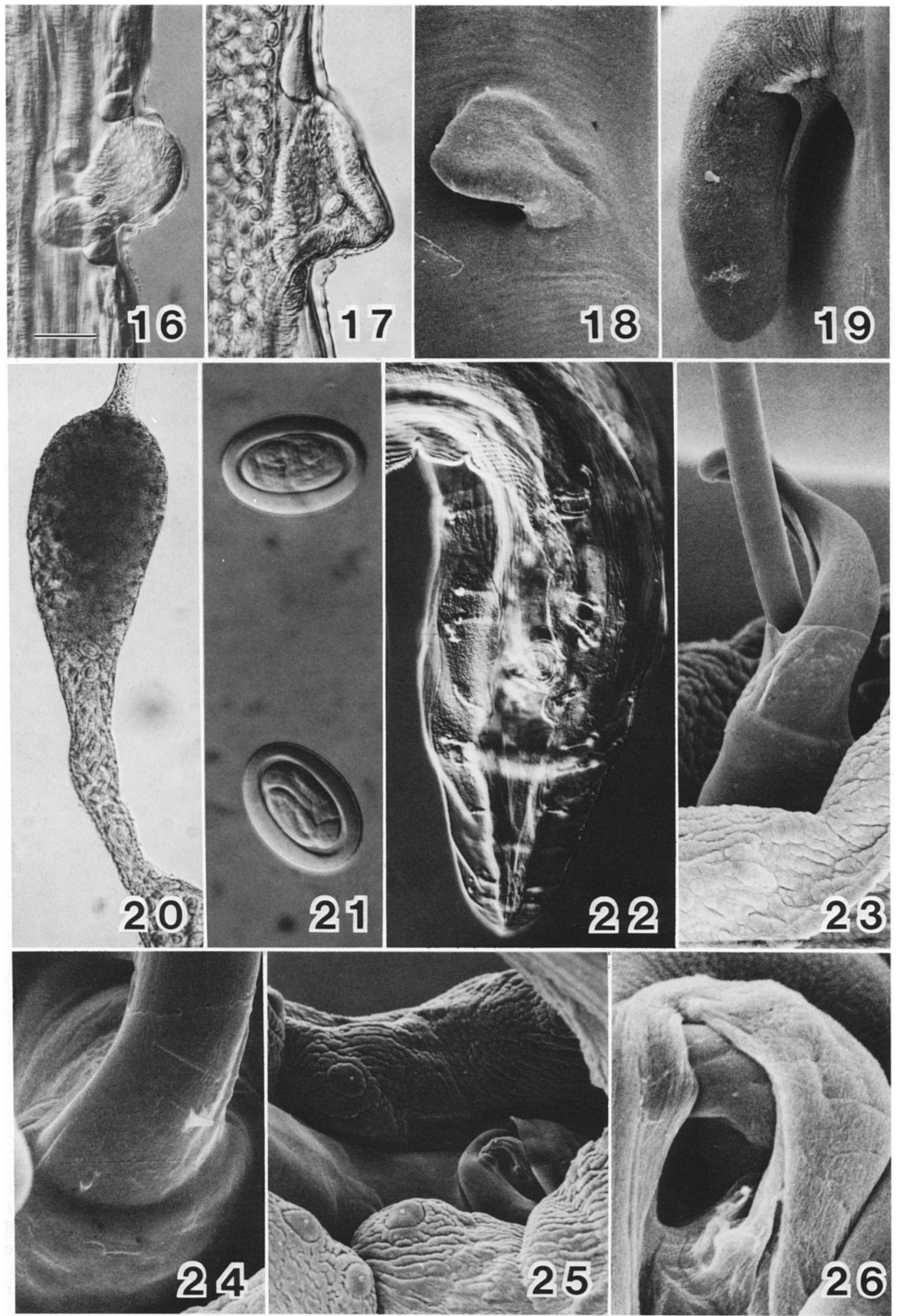


\section{Key to species of the genus Heliconema Travassos, 1919}

1. Males with 14 or more longitudinal ridges in last quarter of body; females with prominent vulvular covers $\ldots \ldots \ldots \ldots \ldots \ldots \ldots \ldots$

Males with fewer than 14 tessellated longitudinal ridges; females with indistinct vulvular covers . .................. 5

2. Males with $\mathbf{1 8}$ or more longitudinal ridges; caudal papillae 10 pairs $\ldots \ldots \ldots \ldots \ldots \ldots \ldots . . . .$.

Males with 14 tessellated longitudinal ridges; caudal papillae 10 pairs; spicule ratio (right: left) averaging $1: 4.2 \ldots \ldots \ldots \ldots \ldots \ldots$ H. psammobatidus Threlfall and Carvajal, 1984

3. Males with 20 longitudinal ridges; caudal papillae 10 pairs $\ldots \ldots \ldots \ldots \ldots \ldots \ldots \ldots 4$

Males with 40 or more tessellated longitudinal ridges; spicule ratio (right: left) averaging 1 : 10.6; caudal papillae 10 pairs $H$. brooksi $\mathrm{n}$. sp.

4. Spicule ratio averaging $1: 12.7$ (and possibly 1 : 20); caudal papillae 10 pairs; longitudinal ridges tessellated present ............. ............ H. heliconema Travassos, 1919

Spicule ratio averaging $1: 2.4$; caudal papillae 10 pairs; longitudinal ridges nontessellated ... . H. brevispiculum Baylis, 1934

5. Males with 12 tessellated longitudinal ridges; caudal papillae 7,9 or 11 pairs; spicule ratios averaging $1: 1.5,1: 2.7$ or $1: 3.7 \ldots \ldots \ldots \ldots 6$

Males with 8-9 tessellated ridges; caudal papillae 8 pairs; spicule ratio averaging $1: 1.7$. ........H. serpens Fusco and Palmieri, 1980

6. Caudal papillae 7 or 11 pairs; precloacal papillae 3 or 4 pairs ............... 7

Caudal papillae 9 pairs; precloacal papillae 4 pairs; spicule ratio averaging $1: 2.7 \ldots \ldots \ldots$ ........... H. longissima Ortlepp, 1923

Spicule ratio averaging $1: 1.5 \ldots \ldots \ldots \ldots \ldots$ ................. H. baylis Ogden, 1969

7. Caudal papillae 7 pairs; precloacal papillae 4 pairs; spicule ratio averaging $1: 3.7 \ldots \ldots \ldots$ H. izecksohni Fabio, 1982

Caudal papillae 11 pairs; precloacal papillae 4 pairs; spicule ratio averaging $1: 1.3 \ldots \ldots \ldots$ ............... ahiri Karve, 1941

The most recent key, one by Fusco and Palmieri (1980), included 6 species; this key adds 3 more species and does not include Heliconema urolophi (Johnston and Mawson, 1951) or Heliconema hamiltonii Bilquees and Khanum, 1970. Several characteristics of the latter 2 species are not established, and as discussed below, 2 their taxonomic status requires reevaluation. Additional characteristics than those used in our key are not described for all species.

\section{DISCUSSION}

The genus Heliconema was reviewed by Ogden (1969), and he recognized 5 species: $H$. heliconema (type species), H. ahiri, $H$. baylisi, $H$. brevispiculum, and $H$. longissima. Bilquees and Khanum (1970) described a sixth species, $H$. hamiltonii, from Mugil hamiltonii. Fusco and Palmieri (1980) indicated that $H$. hamiltonii was a species inquirenda because the description and drawings of 14 females and no male did not agree with the emended generic description given by Ogden (1969). We agree with that determination. Specian et al. (1975) tentatively transferred Proleptus urolophi to Heliconema because the vulva was reported anteriorly near the esophagus rather than adjacent to the tail like in other species of Proleptus. The status of the species requires a critical examination of the arrangement of cephalic teeth as well as other characters presently used for differentiation of species in Heliconema and related genera. Fusco and Palmieri (1980) described $H$. serpens and confirmed the occurrence of a species of Heliconema in snakes, and Fabio (1982) described $H$. izecksohni from the carnivorous characoid fish Hoplias malabaricus. Threlfall and Carvajal (1984) described H. psammobatidus from a Chilean skate, Psammobatis lima.

Most species of Heliconema have been found in anguilliform fishes, but others have also been reported from other teleosts, skates, rays, and snakes. The genus has a wide geographic distri-

FIGURES 16-26. Heliconema brooksi $\mathrm{n}$. sp. from the shrimp eel; scale bar on Figure 16 serves all figures. 16. Photomicrograph of vulvular projection as usually viewed, lateral view; bar $=86 \mu \mathrm{m}$. 17. Photomicrograph of optical lateral section showing vulvular flap; bar $=88 \mu \mathrm{m}$. 18. SEM of the vulvular flap in lateral orientation; $\mathrm{bar}=49 \mu \mathrm{m}$. 19. SEM of the vulvular flap showing vulvular opening on its medial posterior margin; bar $=19$ $\mu \mathrm{m}$. 20. Anterior seminal receptacle containing both spermatozoa and ova. Note valve anteriorly where oviduct enters the receptacle and posteriorly where receptacle joins the uterus; bar $=83 \mu \mathrm{m}$. 21. Larvated eggs with relatively thick shell; bar $=17 \mu \mathrm{m}$. 22. Posterior end of male, ventral view, demonstrating relationship of caudal papillae to alae and cloacal vent and their association with the hypodermis; bar $=81 \mu \mathrm{m}$. 23. SEM of both spicules protruded, lateral view. Note that the right spicule is hooked with distal end serving as a guide for the long left spicule. Both spicules extend from a sheath formed from the unfolded inner lip of the genital bulb; bar $=10 \mu \mathrm{m}$. 24. SEM of protruded spicules extending from the genital bulb, ventral view; bar $=4.8 \mu \mathrm{m}$. 25. SEM of part of male posterior end with circular sensilla in the rugose ventral alar surfaces, and the median genital bulb with its transverse outer and enfolded inner lips of cloacal vent; bar $=18 \mu \mathrm{m}$. 26. Close up of genital bulb shown in Figure 25; bar $=2.8 \mu \mathrm{m}$. 

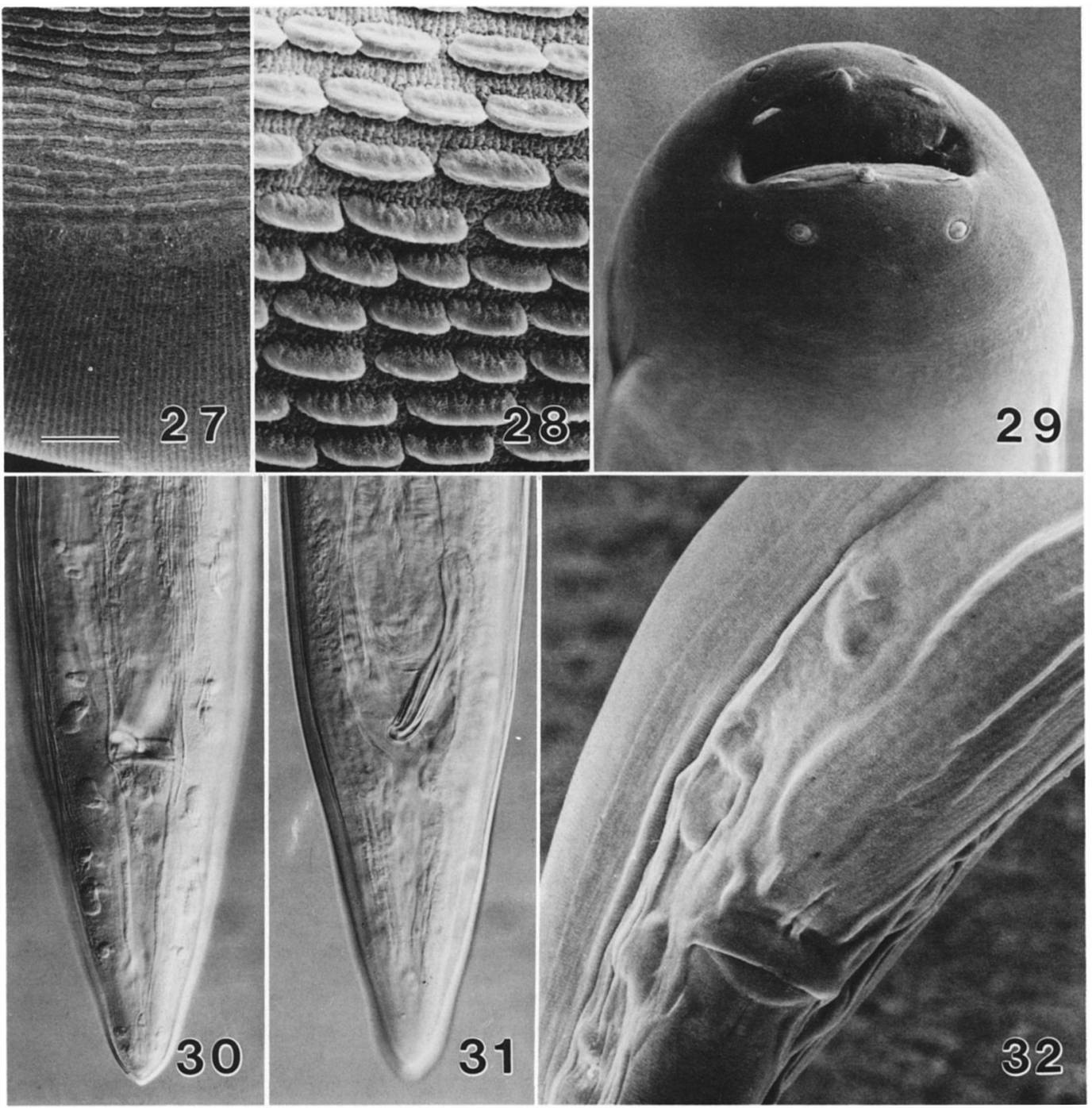

FIGURES 27-32. Heliconema brooksi sp. n. from the shrimp eel; scale bar on Figure 27 serves all figures. 27. SEM of ventral, longitudinal tessellated ridges abutting border of the cuticular annuli; bar $=13 \mu \mathrm{m}$. 28. SEM of loaf-shaped crests that form the longitudinal tessellated ridges; bar $=2.8 \mu \mathrm{m}$. 29. SEM of anterior end of fourth stage juvenile male. Note that the distributional pattern of the papillae is already established, but that the collarette is not conspicuous; bar $=13 \mu \mathrm{m}$. 30. Photomicrograph of the posterior end of fourth stage male. Note the caudal papillae seen under the alar cuticle posteriorly and the longitudinal ridges seen on the surface anteriorly; bar $=88 \mu \mathrm{m}$. 31. Photomicrograph of the posterior end of the same fourth stage male, ventral view, focused to show the hooked right spicule; bar $=88 \mu \mathrm{m}$. 32. SEM of the posterior end of the fourth stage male. Note where the cuticle covers the developing papillae, sensilla, and ridges; $b a r=20 \mu \mathrm{m}$.

bution; species have been reported from Trinidad, Brazil, Chile, the Gulf of Mexico, western Africa, South Africa, Australia, the Indian Ocean, Pakistan, India, Malaysia, Japan, and China.

Several morphological characteristics of $H$. brooksi may be present in other species of $\mathrm{Hel}$ iconema, but they have seldom if ever been re- ported. The anterior end of $H$. brooksi is encircled by an inflated collarette that can be seen clearly in living worms. We found that the collarette collapsed when these nematodes were heat killed or fixed in Karnovsky's solution (Figs. 2, 8). The collarette remained inflated in specimens fixed in glacial acetic acid and stored in $70 \%$ 
ethanol or $10 \%$ buffered formalin (Figs. 1, 2, 7). The muscular esophagus is divided into anterior and posterior regions, as demonstrated by a change in tissue orientation resulting in a transverse demarcation. The nerve ring surrounds the posterior region (Figs. 1, 2, 7). The esophagealintestinal valve of $H$. brooksi is a conspicuous organ, encompassing the entire posterior end of the glandular esophagus. The esophageal lining forms thick, sclerotized ridges surrounding a nearly spherical chamber, which empties posteriorly through 3 relatively large cardial valves into the intestine (Fig. 13). The shape of the female tail of $H$. brooksi varies, depending upon the size of the worm. Larger females of $H$. brooksi usually have more blunt tails than smaller ones (Figs. 10, 14, 15), indicating that care must be taken designating size or age of specimens when or if differentiating species by tail shape. Fusco and Palmieri (1980) were the only authors to mention the seminal receptacles of Heliconema. At the proximal end of each oviduct in $\mathrm{H}$. brooksi, a muscular sphincter entered a pyriform seminal receptacle (Fig. 20). The seminal receptacle contained both spermatozoa and eggs. Ova entering the seminal receptacle from the oviduct were irregular in shape; however, in the lumen of the seminal receptacle, the ova assumed a definite ovoid outline and became enveloped with a firm shell having a thick, clear, outer coat before they entered the uterus. Fertilization appears to occur in the seminal receptacle, and the clear outer layer of the shell may be formed from secretions of the cells lining this organ before the eggs enter uteri.

SEM reveals some features of $H$. brooksi lucidly. The pattern and distribution of psuedolabial teeth, papillae, and amphids (Figs. 8, 9) match well the generic diagnosis presented by Ogden (1969). All species of Heliconema fit this psuedolabial arrangement except $H$. urolophi described by Johnston and Mawson (1951). As indicated earlier, that species was tentatively transferred to Heliconema by Specian et al. (1975), and its taxonomic status requires examination of additional or of type material. Phasmids have not been described for any species of Helicone$m a$, even though for the generic diagnosis, Ogden (1969) mentioned their presence in females. With SEM, however, we clearly saw them on the lateral surface of the female tail of $H$. brooksi (Fig. 11). We did not observe them on males. Deirids have been reported by Ogden (1969) and illustrated for $H$. serpens by Fusco and Palmieri (1980). We
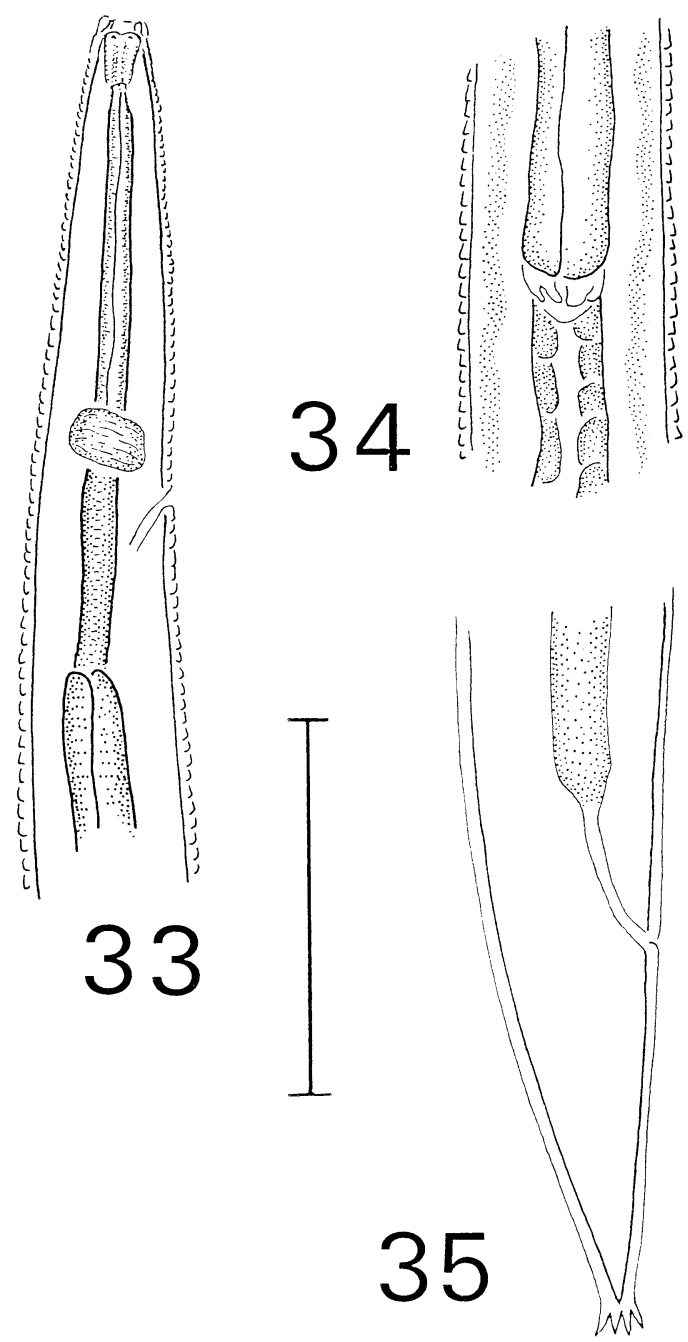

Figures 33-35. Juvenile spiruroid, (?) Heliconema sp., from the white shrimp, Penaeus setiferus; scale bar $=100 \mu \mathrm{m}$ serves all figures. 33. Molting anterior end, lateral view, showing esophagus, nerve ring, and excretory pore. 34. Esophageal-intestinal valve. 35. Molting posterior end showing spinous mucrones.

saw them clearly on the lateral surfaces of $H$. brooksi, and SEM demonstrates that the deirids project above the cuticular surface of both the adult and fourth stage juvenile (Figs. 2, 12). All species of Heliconema are described as having paired, pedunculate caudal papillae, but there has been no published account of sensilla in the alar surface. Ogden (1969) did not mention sensilla, but his illustrations of $H$. baylisi and $H$. longissima indicated that they might be present. The caudal sensory sensilla of adult male $H$. 
brooksi are the circular tips of the papillae that internally traverse the expanded alae and appear on their ventral surfaces (Figs. 5, 6, 22, 25). In adults of $H$. brooksi, these sensilla reflect the distributional pattern of the internal portion of the pedunculatelike structures, 4 precloacal $(2: 2)$ and 6 postcloacal $(1: 2: 1: 2)$. SEM of the fourth stage males of $H$. brooksi showed no surface sensilla of the caudal papillae, but the papillae of the fifth stage as well as the longitudinal ridges appear as bulges under the alar cuticle (Figs. 30, 32). The transverse cloacal vent of $H$. brooksi with its inner and outer lips splits the ventral surface of a prominent, rounded genital bulb found between the alae (Figs. 25, 26). This genital bulb has not been described for any other species of Heliconema. Both spicules of $H$. brooksi can be everted through this bulb with the recurved, hooked, distal tip of the short spicule serving as a guide for the long thin spicule (Figs. 23, 24). The inner lip of the vent is an enfolded membrane surrounding both spicules. The membrane unfolds when the spicules are protruded, confining the spicules close to one another. This membrane appears to be attached to the short spicule, limiting its extension and providing it stability (Figs. 23, 24). The ventral cuticle anterior to the genital bulb in $H$. brooksi is modified, forming rows of loaf-shaped crests that give rise to the tessellated longitudinal ridges (Figs. 27, 28). Heliconema brevispiculum was the only species described as having longitudinal ridges that are nontessellated. Only $H$. heliconema, $\boldsymbol{H}$. brevispiculum, $H$. psammobati$d u s$, and $H$. brooksi have protruding vulvular structures (Figs. 16, 17). Travassos (1919) reported $H$. heliconema as having a vulva with a large superior lip, and Ogden (1969) remarked that $H$. brevispiculum had an "overhanging lip," giving the vulva a swollen appearance. Threlfall and Carvajal (1984) wrote that H. psammobatidus had a protruding conical vulva. SEM of the vulva of $H$. brooksi demonstrated that the orifice of the vagina vera was on the posterior edge of a laterally directed tongue-shaped flap (Figs. 18, 19). The specimens of $H$. heliconema from South America that we examined also appeared to have a vulvular flap, and we suspect that $H$. brevispiculum also has one.

No life cycle of any species of Heliconema has been demonstrated. Ophichthus gomesi feeds heavily on shrimps. The single juvenile described above from shrimp has some features in common with $H$. brooksi, but additional research is required to confirm the identity.

\section{ACKNOWLEDGMENTS}

Dr. Daniel Brooks, Teri Turner, Ronnie Palmer, Marie Wright, Nate Jordan, and Helen Gill, from Gulf Coast Research Laboratory, all provided some technical assistance. Dr. Henrique de Oliveira Rodriques and Joaquim Julio Vicente of Instituto Oswaldo Cruz, Rio de Janeiro, Brazil, provided specimens from Brazil. The study was conducted in cooperation with the U.S. Department of Commerce, NOAA, National Marine Fisheries Service, Grant no. NA90AAD-IJ217 and the U.S. Department of Agriculture, CSRS, Grant no. 88-38808-3319.

\section{LITERATURE CITED}

Bilquees, F. M., AND Z. Khanum. 1970. Marine fish nematodes of West Pakistan II. A new species of the genus Heliconema from fishes of Pasni. Pakistan Journal of Zoology 2: 211-213.

Campana-Rouget, Y. 1956. Parasites de poissons de mer ouest-africains récoltés par J. Cadenat, VI et VII. Nématodes ( $2^{e}$ et $3^{e}$ notes). Bulletin de l'Institut Francais d'Afrique Noire 18A: 459-466.

FABIO, S. P. 1982. Sobre alguns nematoda parasitos de Hoplias malabaricus. Arquivos da Universidade Federal Rural, Rio de Janeiro 2: 286-293.

Fusco, A. C., AND J. R. PAlmieri. 1980. Heliconema serpens sp. $\mathrm{n}$. (Nematoda: Physalopteridae) and Camallanides malayensis sp. $\mathrm{n}$. (Nematoda: Camallanidae) from Cerberus rhynchops (Schneider) (Reptilia: Colubridae) in Malaysia. Proceedings of the Helminthological Society of Washington 47: 72-79.

Guimarães, J. F., R. CRistofaro, AND H. O. RodriGUES. 1976. Alguns nematódeos de Peixes de Salvador, Bahia. Atas da Sociedade de Biologia do Rio De Janeiro 18: 21-25.

Johnston, T. H., AND P. M. Mawson. 1951. Additional nematodes from Australian fish. Transactions of the Royal Society of South Australia 74: 18-24.

OGDEN, C. G. 1969. A revision of the genus Heliconema Travassos, 1919, Physalopteridae (Nematoda). Journal of Natural History 3: 423-431.

SootA, T. D. 1983. Studies on nematode parasites of Indian vertebrates. I. Fishes. Records of the Zoological Survey of India, Miscellaneous Publication, Occasional Paper No. 54, 353 p.

SPeCIAN, R. D., J. E. Ubelaker, AND M. D. Dailey. 1975. Neoleptus gen. $n$. and a revision of the genus Proleptus Dujardin, 1845. Proceedings of the Helminthological Society of Washington 42: 14-21.

Threlfall, W., AND J. Carvajal. 1984. Heliconema psammobatidus sp. n. (Nematoda: Physalopteridae) from a skate, Psammobatis lima (Chondrichthyes: Rajidae), taken in Chile. Proceedings of the Helminthological Society of Washington 51: 208211.

Travassos, L. 1919. Informações sobre o material helminthológico colleccionado na Ilha da Trindade em 1916. Archivos do Museu Nacional, Rio de Janeiro 22: 161-167. 